\section{The StABILITY AND GROWTH PACT: CRISIS AND REFORM}

\author{
LUDGER SCHUKNECHT*, \\ Philippe Moutot*, \\ PhILIPP ROTHER* AND \\ JÜRGEN STARK*1
}

\section{Introduction}

The sovereign debt crisis in the euro area is a symptom of policy failures and deficiencies in - among other things - fiscal policy coordination. ${ }^{2}$ It reflects the as yet unresolved challenge of how to place public finances on a sufficiently sound footing in the $\mathrm{Eu}-$ ropean Monetary Union (EMU). This challenge has been compounded by spillovers from the financial and economic crisis to public finances. The greatly in creased fiscal imbalances in the euro area as a whole and the dire situation in individual member countries risk undermining stability, growth and employment, as well as the sustainability of EMU itself.

Europe's leaders have spent many years grappling with this challenge, beginning with the experience of the 1980s and the nascent plan to establish a monetary union. The founding fathers of EMU embedded fiscal rules in the Maastricht Treaty and the Stability and Growth Pact in the early and mid-1990s. However, after two

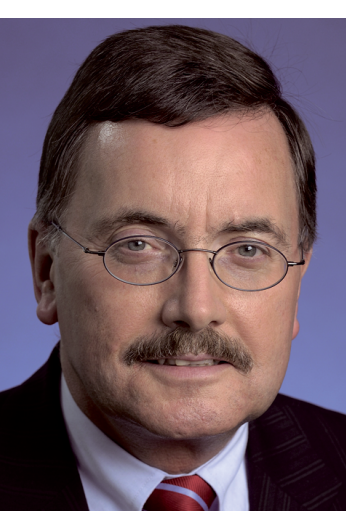

* European Central Bank (ECB).

${ }^{1}$ The views expressed are those of the authors and do not necessarily reflect those of the ECB. The authors are grateful both to Sebastian Hauptmeier and Ad van Riet for their comments and input and to Krzysztof Bankowski for his valuable assistance with research. A longer version of this article will be published as ECB Occasional Paper no. 129.

2 There was also a failure to coordinate policy in a number of other areas, notably financial sector and competitiveness-related structural policies. While occasionally pointing to interlinkages, this paper will consider only fiscal policy.

\section{Figure 1}

rounds of reforms in 2003-05 and 2010-11, scepticism prevails. The latest reforms continue to reflect Member States' unwillingness to transfer the necessary degree of sovereignty over macro-fiscal objectives to the European level.

This paper looks at the history of fiscal policy and rules in EMU before concluding with proposals in the area of fiscal governance that the authors consider essential for effective policy coordination in the future.

\section{The pre-Maastricht period: laying solid foundations?}

The inception of EMU in the early 1990s followed a period characterised by buoyant public expenditure, chronic budget deficits and rapidly rising public debt ratios in many of the future euro area countries. Budget deficits averaged 4-6 percent of GDP during that period (Figure 1). By 1991, public debt averaged almost 60 percent of GDP in the first 12 euro area countries. However, developments differed significantly from country to country.

Many observers and economists warned against establishing EMU without adequate fiscal controls (see Jonung and Drea (2009) for a survey). Con-

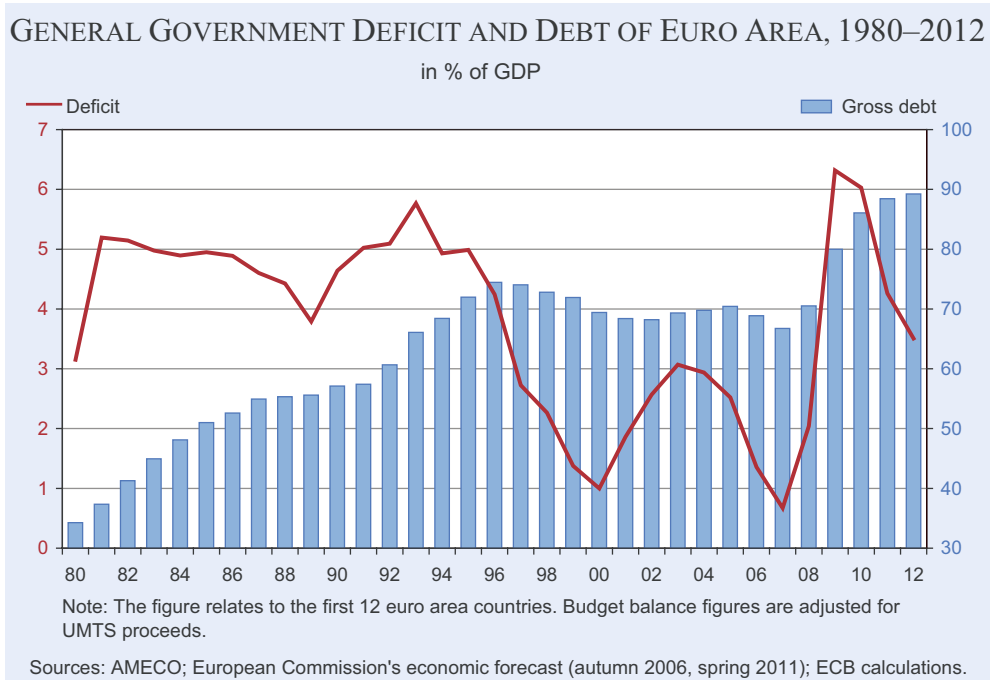


sequently, the founding fathers of EMU ensured that some basic safeguards against fiscal profligacy were enshrined in the Maastricht Treaty: the prohibition of monetary financing of government deficits via central banks; the prohibition of privileged access to financial institutions by the public sector; the "nobailout principle", which precludes the sharing of liability for government debt across Member States; and a requirement to avoid excessive budget deficits and government debt (with reference values of 3 percent of GDP for budget deficits and 60 percent of GDP for government debt).

Two important further institutional elements were introduced. First, eligibility for membership of the euro area was tied to convergence criteria, including a fiscal criterion stipulating that countries must not have an excessive deficit as defined by the Treaty. Second, Member States agreed on the establishment of the Stability and Growth Pact in order to help implement the obligation to avoid excessive deficits as laid down in the Treaty (Stark 2001). The "preventive arm" of the Pact required countries to achieve budgets which were close to balance or in surplus so as to place debt on a sustainable path and create some room to help stabilise demand in times of weak economic activity. And the "corrective arm" of the Pact took the form of the excessive deficit procedure. This aimed to encourage governments to quickly correct deficits in excess of 3 percent of GDP through a sequence of graduated steps involving tighter surveillance and ultimately sanctions.

The Pact's Achilles heel was its weak enforcement provisions (ECB 2008; Schuknecht 2005). First, the Commission, as the institution initiating proceedings, had to get the backing from Commissioners before any procedural steps could be taken. Thus, there was always a risk that the Commission would seek to water down proceedings against countries. Second, a qualified majority was then required in the ECOFIN Council in order to approve further procedural steps. Countries that "sinned" retained the right to vote and needed only a few additional countries - prospective sinners among them - to block such steps.

Initially, however, things got off to a good start, and during the period from 1992 (when the Maastricht Treaty was signed) to 1998 (the year before the introduction of the euro), developments in public finances were remarkably positive (Figure 2). Average deficits improved, falling from almost 5 percent of GDP in 1992 to just over 2 percent in 1998. All of the founding members of the euro area managed to bring their deficits below 3 percent. However, it was arguably the threat of not being allowed to join the euro area that gave rise to this initial success with fiscal consolidation.

\section{The first nine years of the euro: wasting the "good times"?}

The first nine years of the euro - from 1999 to 2007 - can, in retrospect, probably be best characterised as "wasted good times" during which the foundations were laid for the present crisis in EMU. There was little further progress towards sound public finances, while the credibility of fiscal rules was compromised. Almost as soon as the euro had been introduced, consolidation fatigue set in. Fiscal policies were broadly relaxed, especially during the mild downturn of the early 2000s, and the lower interest rates achieved thanks to EMU were used for increases in primary spending and tax cuts (ECB 2004; Hauptmeier et al. 2011). After reaching a cyclical low of 1 percent of GDP in 2000, average euro area deficits worsened again, rising to around 3 percent in 2003 (Figure 2). Several countries (including not only Greece, Portugal and Italy, but also France and Germany) breached the 3 percent threshold for deficits. This stands in contrast, in particular, to Italy's commitment, made prior to the introduction of the euro, to record significant budget surpluses. Average public debt also began rising again.

When it came to implementing the Stability and Growth Pact in a rigorous manner, the first test was failed. Faced with a need to fully apply the provisions of the corrective arm of the Pact in the autumn of 2003, France and Germany, among others, blocked its strict implementation by colluding in order to reject a Commission recommendation to move a step further in the direction of sanctions under the excessive deficit procedure. The Commission, with the support of governments and academics, responded by proposing a reform of the Stability and Growth Pact (Fischer et al. 2006). This aimed to increase countries' ownership of the process by having them define their own country-specific medium-term objectives for fiscal balances. But otherwise, the reform, which was agreed in early 2005, introduced greater discretion, leniency and political control into procedures. The strictness of the 3 percent limit and the time frame for correcting excessive deficits were relaxed, while procedural deadlines were extended. 
Figure 2

FISCAL DEVELOPMENTS

change in percentage points of GDP

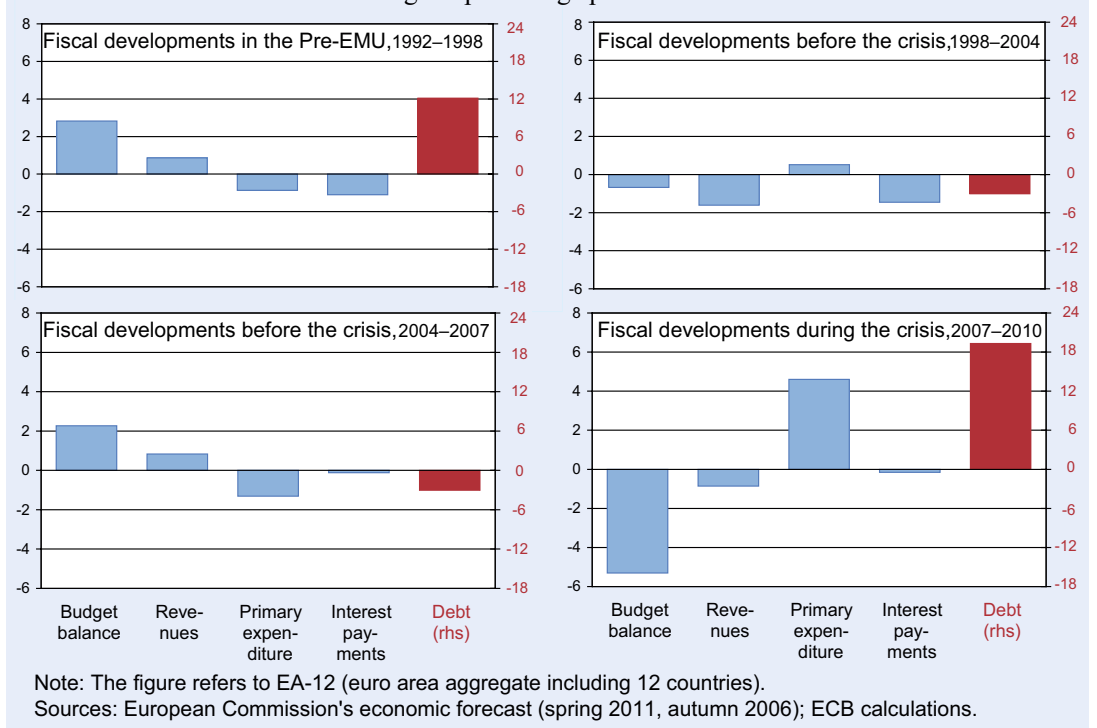

significant consolidation, despite favourable economic developments. Strong growth and buoyant revenues owing to an unprecedented boom in real estate markets helped to disguise the expansionary expenditure policies of a number of countries (Hauptmeier et al. 2011). According to the data available at the time, all countries appeared to have brought their deficits below 3 percent, although France, Italy and Portugal remained very close to the 3 percent limit in 2007. Deficit data for Portugal and (notably)

The greater complexity of the rules made monitoring by markets and the public more difficult. Nothing was done to improve the incentives for strict implementation by the Commission and effective enforcement in the ECOFIN Council (Morris et al. 2006; Calmfors 2005). During negotiations regarding the reform of the Pact, the ECB pointed to the risks entailed by watering down the institutional framework, and in March 2005 it expressed serious concerns regarding the outcome (ECB 2005).

The implementation of the revised Pact was lenient. Significant extensions were immediately observed for deadlines under the excessive deficit procedure, and limited adjustment efforts were required. In the case of Greece, an excessive deficit procedure was abrogated in 2007 on the basis of a Commission proposal, despite significant concerns being repeatedly expressed by the ECB regarding the reliability of data and policy commitments - concerns which proved to be justified in 2009, when massive statistical misreporting became apparent. ${ }^{3}$ The scope for tighter surveillance and increased peer pressure was not used in a decisive manner either.

Nevertheless, a renewed improvement was then seen in fiscal balances in the period prior to 2007 (Figure 2). The average euro area deficit declined to 1 percent of GDP. But this improvement was modest in cyclically adjusted terms. Few countries undertook

${ }^{3}$ An early reference to such concerns can be found in the Greek chapter of the ECB's Convergence Report in 2000.
Greece were later revised to more than 3 percent of GDP. Average public debt in the euro area declined only marginally during the first nine years of the euro, standing at 66 percent of GDP in 2007.

Moreover, in the favourable financial environment prior to 2007, markets' scrutiny of - and differentiation between - the sovereign debt of euro area countries was minimal, such that the worst-performing countries paid only a few basis points more than the best. Thus, the euro area as a whole and many of its individual member countries were distinctly ill-prepared when the financial crisis erupted in the summer of 2007.

\section{The crisis}

In response to the financial and economic crisis, governments adopted a range of measures, notably in order to stabilise the financial sector and support overall economic activity (van Riet 2010). In the EU, support for the economy was generally coordinated under the "European Economic Recovery Plan" (EERP) launched by the European Commission. This foresaw coordinated short-term budgetary stimulus in order to strengthen demand by around 1.5 percent of GDP. This stimulus came on top of the effect of automatic fiscal stabilisers, which were generally left to operate freely. Further explicit and contingent government liabilities stemmed from support for the financial sector and the reduction of systemic risks. Some of the most important measures were capital injections for weak banks and the provision of government guarantees for both depositors and banks issuing bonds. 
As a consequence of the poor starting position, the deep economic downturn, fiscal expansion and support for the financial sector, public finances deteriorated significantly in the euro area (Figure 2). The average deficit increased by more than 5 percentage points, reaching 6.0 percent of GDP in 2010, as the dynamics of public expenditure failed to adjust to changes in the level and dynamics of output and public revenues. Ireland's record deficit of 32.4 percent (which included one-off support for the banking sector) dwarfed the next three largest deficits, which stood at around 10 percent of GDP. Average public debt reached 85 percent of GDP in the euro area, almost 20 percentage points above the pre-crisis level. Five countries had debt ratios approaching or exceeding 100 percent. In the case of Greece, misreporting of data on government finances aggravated concerns. Between autumn 2009 and spring 2011 access to liquidity in financial markets dried up first for Greece and then for Ireland and Portugal (Rother et al. 2011). These countries were forced to seek financial support. In order to establish an institutional framework for such operations, the European Financial Stability Facility (EFSF) was set up in 2010 and tasked with providing emergency financing until 2013. Thereafter, the European Stability Mechanism (ESM) is set to take over this role.

From a policy coordination perspective, these developments under the EERP proved problematic. The agreed increase in deficits above the reference value represented a de facto suspension of the requirements laid down in the Stability and Growth Pact (see Chapter 6 in van Riet 2010). And stimulus programmes generally failed to provide for credible exit strategies, leaving doubts as to how and when sound public finance positions would be regained.

\section{The new reform: an opportunity} wasted?

Given current fiscal deficits, debt dynamics and additional contingent and implicit liabilities for the budget (such as those stemming from the financial sector or popu-

\section{Table 1} 2011). lation ageing), major fiscal adjustment will be needed in almost all euro area countries over a long period of time in order to ensure fiscal sustainability. Table 1 provides an overview of the fiscal situation and adjustment needs in the euro area countries, showing that most countries will have to undertake sizeable and lasting consolidation efforts in order to reach sound fiscal positions in line with their medium-term budgetary objectives. ${ }^{4}$ In their stability programmes, euro area countries set themselves such objectives with a view to achieving budgetary positions that guard against the risk of breaching the 3 percent threshold laid down in the Treaty and ensure the longterm sustainability of public finances.

A consensus exists that a sound framework for governance is a prerequisite for successful and sustainable fiscal policies in EMU and that a "quantum

${ }^{4}$ In fact, in certain other advanced economies the fiscal situation is probably even more serious than that seen in the euro area as a whole and the majority of the individual member countries. Table 1 therefore also provides information on Japan, the United Kingdom and the United States.

Fiscal situation and adjustment needs in the euro area, Japan, the United Kingdom and the United States, in \% of GDP

\begin{tabular}{|c|c|c|c|c|}
\hline & $\begin{array}{l}\text { Govern- } \\
\text { ment } \\
\text { budget } \\
\text { balance }\end{array}$ & $\begin{array}{l}\text { Govern- } \\
\text { ment gross } \\
\text { debt }\end{array}$ & $\begin{array}{c}\text { Required fiscal } \\
\text { adjustment and } \\
\text { age-related } \\
\text { spending increase }\end{array}$ & $\begin{array}{l}\text { Country- } \\
\text { specific } \\
\text { MTO }\end{array}$ \\
\hline & 2010 & 2010 & $2010-30$ & \\
\hline Belgium & -4.1 & 96.8 & 8.7 & 0.5 \\
\hline Germany & -3.3 & 83.2 & 4.4 & -0.5 \\
\hline Estonia & 0.1 & 6.6 & -3.1 & $>0$ \\
\hline Ireland & -32.4 & 96.2 & 14.4 & -0.5 to 0 \\
\hline Greece & -10.5 & 142.8 & 14.0 & 0 \\
\hline Spain & -9.2 & 60.1 & 10.3 & $>0$ \\
\hline France & -7.0 & 81.7 & 8.4 & 0 \\
\hline Italy & -4.6 & 119.0 & 4.6 & 0 \\
\hline Cyprus & -5.3 & 60.8 & n.a. & 0 \\
\hline Luxembourg & -1.7 & 18.4 & n.a. & 0.5 \\
\hline Malta & -3.6 & 68.0 & n.a. & 0 \\
\hline Netherlands & -5.4 & 62.7 & 9.5 & $>-0.5$ \\
\hline Austria & -4.6 & 72.3 & 6.7 & 0 \\
\hline Portugal & -9.1 & 93.0 & 10.6 & -0.5 \\
\hline Slovenia & -5.6 & 38.0 & 7.7 & 0 \\
\hline Slovakia & -7.9 & 41.0 & 8.9 & 0 \\
\hline Finland & -2.5 & 48.4 & 6.6 & 0.5 \\
\hline Euro area & -6.0 & 85.4 & 7.1 & \\
\hline $\begin{array}{l}\text { Memorandum items } \\
\text { Japan } \\
\text { United Kingdom } \\
\text { United States }\end{array}$ & $\begin{array}{r}-9.5 \\
-10.4 \\
-11.2\end{array}$ & $\begin{array}{r}220.3 \\
80.0 \\
92.0\end{array}$ & $\begin{array}{l}14.0 \\
13.5 \\
17.5\end{array}$ & \\
\hline
\end{tabular}

Notes: The required fiscal adjustment and age-related spending increase is derived from the IMF's Fiscal Monitor. This is the sum of: (i) the fiscal adjustment needed to bring the debt ratio to $60 \%$ of GDP by 2030 (or stabilise the ratio at the 2012 level if the ratio is below $60 \%$ ); and (ii) the projected increase in healthcare and pension expenditure between 2010 and 2030 .

Sources: European Commission economic forecasts (spring 2011), the IMF's World Economic Outlook (April 2011) and the IMF's Fiscal Monitor (April 
leap" in this regard is needed.5 Despite the initial enthusiasm for the reform of governance in the midst of the crisis, the process of building political consensus on the ambitious and far-reaching reforms that are needed has proven cumbersome. After more than a year of negotiations by the parties involved - mainly national governments, the European Commission and the European Parliament - the compromise expected to be agreed in the autumn of 2011 falls short of the necessary ambition (ECB 2011; see Table 2).

In the fiscal domain, changes focus on four areas:

- a directive establishing minimum standards for domestic fiscal rules;

- stronger regulation under the preventive arm of the Pact as part of a broader annual review process (the "European Semester"), greater emphasis on spending controls and some scope for financial sanctions;

- stronger regulation under the corrective arm of the Pact with more of a focus on reducing public debt;

- greater scope for financial and non-financial sanctions via a new regulation applicable to euro area countries.

While the reforms go in the right direction, it is far from clear whether they will be sufficient to ensure sound fiscal policies. The envisaged common approach to stronger domestic fiscal rules is insufficient, and it is unclear whether countries will make meaningful changes to domestic arrangements. There will have to be clear consequences in the event that national authorities fail to comply with their budgetary obligations. Independent national monitoring institutions are essential. As has been shown by recently announced changes to domestic fiscal rules in countries under immediate pressure from financial markets, the reform of national fiscal rules needs to lead to binding and enforceable provisions in order to convince market participants. This is also in line with the findings of empirical studies, which have consistently shown that strong domestic rules can make a significant contribution to the conduct of sound fiscal policies.

\footnotetext{
${ }^{5}$ Restoring and maintaining fiscal sustainability is also closely linked to the need for a quantum leap in the coordination of financial sector regulation and supervision. This should help ensuring that financial institutions are sufficiently strong to absorb significant shocks which would otherwise burden the public balance sheet. In fact, these fiscal burdens have proven in many cases to be a significant contributor to the public debt increase in recent years and in one country, Ireland, even to the fiscal crisis. Progress has and in one country, Ireland, even to the fiscal crisis. Progress has
been made in this domain with the formation of the ESRB for macro financial stability and the three European level institutions, EBA, EIOPA and ESMA for banking, insurance and security market supervision.
}

Under the preventive arm of the revised framework, the monitoring of expenditure will probably play only a secondary role. While the focus on deficit developments is appropriate, experience shows that slippages in budgets result mainly from governments' failure to adhere to prudent expenditure plans. Thus, there is a need for immediately binding provisions on expenditure policies. This is also in line with the findings of numerous studies showing that expenditure restraint and well-designed expenditure rules are a key ingredient in successful consolidation and the maintenance of sound public finances (Holm-Hadulla et al. 2011).

The proposed stronger focus on debt developments under the corrective arm is welcome, but the precise nature of the debt rule raises doubts as to its effectiveness. A long transition period precedes the full implementation of the rule, while the provision itself refers to multi-year averages and projected debt developments and requires that a long list of special factors be taken into account. This suggests that the debt rule may rarely reinforce the excessive deficit procedure. Moreover, for high-debt countries, nominal GDP growth would automatically contribute to the reduction of debt ratios. This would thereby reduce the incentive for governments to undertake structural adjustment efforts, especially during periods of strong economic activity.

Timely and reliable statistics are a key prerequisite for the effective implementation of the governance framework. It is questionable whether the changes adopted in order to strengthen statistical governance will be sufficient in this regard. The underlying statistical rules are not enshrined in a regulation, and sanctions for statistical misreporting do not go far enough. Moreover, stronger emphasis on the professional independence of national statistical institutes would counteract the risk of increasing political pressure as public scrutiny of fiscal data increases.

Most importantly, the new provisions still leave a considerable degree of administrative and political discretion at each stage of the process. As past experience with the EU's fiscal framework has shown, any leeway risks being exploited in the interests of short-term political considerations at the expense of consistent and rigorous implementation. The new provisions do not foresee greater independence for the Commission services in its administration of the Pact, and limitations on member countries' right of veto via more inclusive majority rules concern only a 
Table 2

\begin{tabular}{|c|c|}
\hline Key procedural steps & Financial sanctions \\
\hline \multicolumn{2}{|l|}{ Preventive arm } \\
\hline \multicolumn{2}{|l|}{$\begin{array}{l}1 \text { Member States submit stability and convergence programmes by } \\
\text { April }\end{array}$} \\
\hline \multicolumn{2}{|l|}{$\begin{array}{l}2 \text { The Council issues opinions on stability and convergence programmes } \\
\text { before the end of July and may invite a Member State to adjust its } \\
\text { programme }\end{array}$} \\
\hline \multicolumn{2}{|l|}{$\begin{array}{l}3 \text { In the event of a significant deviation from the approved adjustment } \\
\text { path the Commission may issue a warning to a Member State }\end{array}$} \\
\hline \multicolumn{2}{|l|}{$\begin{array}{l}4 \text { The Council issues a recommendation to the Member State to take } \\
\text { effective action }\end{array}$} \\
\hline \multicolumn{2}{|l|}{5 The Member State reports to the Council on the action taken } \\
\hline $\begin{array}{l}6 \text { If the action is considered insufficient, the Council issues a } \\
\text { recommendation to the Member State }\end{array}$ & $\begin{array}{l}\text { Interest-bearing deposit ( } 0.2 \% \text { of GDP) im- } \\
\text { posed by reverse qualified majority vote } \\
\text { (proposed new sanction) }\end{array}$ \\
\hline \multicolumn{2}{|l|}{ Corrective arm } \\
\hline \multicolumn{2}{|l|}{$\begin{array}{l}1 \text { The Commission prepares a report on any Member State exceeding } \\
\text { the reference value for debt and/or deficit, taking account of relevant } \\
\text { factors }\end{array}$} \\
\hline $\begin{array}{l}2 \text { The Council declares the existence of an excessive deficit and issues } \\
\text { recommendations to the Member State }\end{array}$ & $\begin{array}{l}\text { Non-interest-bearing deposit }(0.2 \% \text { of } \\
\text { GDP) imposed by reverse qualified majority } \\
\text { vote (proposed new sanction) }\end{array}$ \\
\hline \multicolumn{2}{|l|}{3 Report on the effective action taken by the Member State concerned } \\
\hline \multicolumn{2}{|l|}{4 The Council assesses the effective action taken } \\
\hline $\begin{array}{l}5 \text { If the action is considered sufficient, the excessive deficit procedure is } \\
\text { held in abeyance or, in the case of unexpected adverse economic } \\
\text { developments, the deadline is extended. If the action is considered } \\
\text { insufficient, the Council issues a decision on the lack of effective } \\
\text { action }\end{array}$ & $\begin{array}{l}\text { Fine ( } 0.2 \% \text { of GDP) imposed by reverse } \\
\text { qualified majority vote (proposed new } \\
\text { sanction) }\end{array}$ \\
\hline \multicolumn{2}{|l|}{$\begin{array}{l}6 \text { The Council gives notice to the Member State to take measures to } \\
\text { correct the excessive deficit }\end{array}$} \\
\hline \multicolumn{2}{|l|}{$\begin{array}{l}7 \text { The Member State may be subject to additional reporting and } \\
\text { surveillance }\end{array}$} \\
\hline \multicolumn{2}{|l|}{8 Report on the effective action taken by the Member State concerned } \\
\hline $\begin{array}{l}9 \text { If the action is considered sufficient, the excessive deficit procedure is } \\
\text { held in abeyance or, in the case of unexpected adverse economic de- } \\
\text { velopments, the deadline is extended. If the action is considered in- } \\
\text { sufficient, the Council can apply or intensify measures as long as the } \\
\text { Member State fails to comply with the recommendation. Such meas- } \\
\text { ures include a requirement to publish additional information, an invi- } \\
\text { tation to the European Investment Bank to reconsider its lending po- } \\
\text { licy towards the Member State concerned, or the imposition of a fine }\end{array}$ & $\begin{array}{l}\text { Fine (maximum of } 0.5 \% \text { of GDP) imposed } \\
\text { by majority vote. This sanction is already an } \\
\text { option under the existing framework }\end{array}$ \\
\hline
\end{tabular}

Source: ECB (2011), "The Reform of Economic Governance in the Euro Area - Essential Elements", Monthly Bulletin, March.

few procedural steps. Moreover, the monitoring and implementation of the rules has become even more complex. The reforms do not foresee an independent fiscal body at the euro area level for the purposes of monitoring national fiscal policies and the consistent implementation of the fiscal framework. All in all, the changes envisaged do not represent the "quantum leap" in the euro area's fiscal surveillance which is necessary to ensure its stability and smooth functioning.

At the same time, other incentives for national policy-makers have gained in importance, and these may help to improve the overall soundness of policies. First, the crisis has forced euro area governments to provide support for other countries, at considerable political cost at the domestic level. This experience may well encourage national governments to exercise more peer pressure. And second, financial market pressure, which was largely dormant prior to the crisis, has now returned in force and seems likely to remain. However, despite these considerations, it is questionable whether the revised governance framework will be implemented in a rigorous manner, so that the prospects for sound public finances are highly uncertain. 


\section{Towards a new fiscal order for the euro area}

Fiscal policies in the euro area are at a crossroads. A credible institutional framework is necessary for both a return to sound public finances and the smooth functioning of EMU. The institutional framework that is expected to be agreed at the European level is a step in the right direction. However, serious doubts and concerns regarding the effectiveness of the revised fiscal framework remain. Given the relatively modest returns from the ongoing reform process, which began with the highest of expectations and announcements of serious commitment from all parties involved, it appears that fundamental deepening of fiscal policy surveillance and coordination will be necessary.

Where do we go from here? The identification of the necessary reforms has to begin with the ultimate objective: institutional arrangements which provide credible incentives for sound fiscal policies. ${ }^{6}$ This would require the transfer of sovereignty to a central institution with much stronger powers (Trichet 2011), in combination with stricter rules on the preparation and implementation of budgets at the national level. However, the transfer of sovereignty should be limited to what is necessary in order to achieve the objective, with the agreement process not being burdened or complicated by additional goals. The transfer of sovereignty should be consistent with the rights established in the original arrangements for EMU - i.e. in line with both the division of responsibilities set out in the Lisbon Treaty and the apparent will of the people of the euro area. The following should be noted in this respect:

a) further reforms cannot start from scratch, and any proposals need to be consistent with and/or build on the existing institutional framework;

b) in return for membership of the euro area, countries must agree to give up sovereignty over macro-fiscal objectives (notably as regards government deficits and debt);

c) in line with the principle of subsidiarity, the composition and level of budgetary expenditure and revenue must remain the responsibility of Member States;

d) responsibility for government financial obligations must also remain with Member States.

More concretely, the following elements need to be added to the governance framework.

${ }^{6}$ Sound institutions for financial sector and macro/competitiveness surveillance that prevent the emergence of fiscal liabilities via these channels are essential complements.
1) Fiscal policy: preparation of budgets

- All planned deficits in excess of 3 percent of GDP have to be approved unanimously by euro area governments. All planned deficits in excess of a country's medium-term objective have to be approved by qualified majority. National legislation must recognise this need for approval at the European level. Approval could be granted by the ECOFIN Council. ${ }^{7}$

2) Fiscal policy: implementation of budgets

- A commitment to correct past fiscal slippages automatically in upcoming budgets with essentially no room for discretion. This could be achieved by means of rules similar to the German "debt brake" ("Schuldenbremse"), where structural fiscal slippages are recorded in a special account that has to be balanced over time.

\section{3) The ESM}

- A country requiring assistance under the ESM is placed in financial receivership if its adjustment programme fails to remain on track, with the planning and execution of budgets requiring the agreement of the appointed financial receiver.

\section{4) Sanctions}

- All Member States agree to implement full automaticity regarding fines and sanctions beyond the Stability and Growth Pact.

- Under the corrective arm, euro area countries with an actual deficit in excess of 3 percent of GDP (after 2013) pay an automatic fine of 0.2 percent of GDP for all but the first year that the country records such a deficit. (It would be preferable to have such a fine in the first year, too, but the revised Pact already foresees the provision of a deposit in that year.)

5) Institutional arrangements at the national and euro area levels

- At the national level, all countries introduce an independent budget office that produces independent forecasts.

- An independent entity at the euro area level assesses national policies and the proper implementation of governance procedures. This entity also acts as the monitoring body and administrator for ESM programmes. The entity has a clear mandate and its independence from political interference is ensured by a strong in-

${ }^{7}$ Other proposals often refer to the creation of a - vaguely defined - Ministry of Finance. Our proposal would not require the establishment of such an institution, but would not preclude it either. 
stitutional framework. Such an entity - a European Budget Office - could be located within the European Commission or set up as a new euro area institution. It could potentially form the nucleus of what could become over time and in a step-wise manner a European Ministry of Finance.

As regards those elements that would go beyond the current Treaty framework, such as fully automatic fines, it would be preferable to make the necessary amendments to that framework. However, if this were not possible or proved to be excessively timeconsuming, euro area countries could conclude an intergovernmental agreement.

Agreement on the proposals made in points 1 to 4 above may be feasible in the current circumstances, as the consequences of failed policies are becoming ever clearer. As regards the first element, prior approval of budgets for high-deficit countries is essentially an extension of the idea underlying the European Semester. The second element - i.e. the debt brake approach - brings added automaticity to the concept already underlying the preventive arm of the Pact. It is fully consistent with the agreement reached at the Franco-German summit of 16 August 2011 to the effect that balanced budget rules should be introduced in Member States' national legislation. Indeed, strong debt brakes should form part of national rules.

As regards the third element, financial receivership is necessary where countries have no political consensus in support of reforms. Without such a provision, the moral hazard emanating from support programmes and the risk of countries failing to comply and/or defaulting would not be sufficiently mitigated. This is the ultimate step in a graduated process of increased monitoring and control over national budgetary policies.

The fourth element - i.e. accelerated sanctions should solve the problem that delinquent countries ultimately receive support in the form of assistance programmes, rather than facing sanctions. Automatic fines strengthen incentives to undertake corrective action long before a country requires financial support. Economically, one could see such fines also as an insurance premium given the increased prospect of needing a programme with financial support later.
As regards the proposals made in point 5 , the benefits of independent fiscal authorities at the national level are widely acknowledged, so transposing the approach to the euro area level would be a logical extension of this idea. This would give rise to the independent generation of macroeconomic assumptions and forecasts, which is a prerequisite for the sound planning and implementation of budgets. Independent assessment of governments' policies enhances transparency and adds to pressure to conduct sound policies. At the same time, it is clear from past experience that, at the euro area level, only a strong and independent institution can compensate for member countries' tendency towards leniency in the implementation of fiscal rules.

\section{References}

Calmfors, L. (2005), "What Remains of the Stability Pact and What Next?" SIEPS Reports no. 8, Swedish Institute for European Policy Studies, November.

European Central Bank (2011), "The Reform of Economic Governance in the Euro Area - Essential Elements", Monthly Bulletin, March.

European Central Bank (2008), "Ten Years of the Stability and Growth Pact”, Monthly Bulletin, October.

European Central Bank (2005), Statement of the Governing Council on the ECOFIN Council's Report on Improving the Implementation of the Stability and Growth Pact, 21 March.

European Central Bank (2004), "EMU and the Conduct of Fiscal Policies", Monthly Bulletin, January.

European Central Bank (2000), Convergence Report 2000.

Fischer, J., L. Jonung and M. Larch (2006), "101 Proposals to Reform the Stability and Growth Pact. Why So Many? A Survey", European Economy - Economic Papers no. 267, European Commission, December.

Hauptmeier, S., A. J. Sanchez-Fuentes and L. Schuknecht (2011), "Towards Expenditure Rules and Fiscal Sanity in the Euro Area", Journal of Policy Modeling 3(4), July-August.

Holm-Hadulla, F., S. Hauptmeier and P. Rother (2011), "The Impact of Numerical Expenditure Rules on Budgetary Discipline over the Cycle", Applied Economics, forthcoming.

Jonung, L. and E. Drea (2009), “The Euro: It Can’t Happen. It's a Bad Idea. It Won't Last. US Economists on the EMU, 1989-2002", European Economy - Economic Papers no. 395, European Commission, December.

Morris, R., H. Ongena and L. Schuknecht (2006), "The Reform and Implementation of the Stability and Growth Pact", Occasional Paper Series no. 47, European Central Bank, June.

Rother, P., L. Schuknecht and J. Stark (2011), More Gain than Pain - Consolidating the Public Finances, Politeia, May.

Schuknecht, L. (2005), "Stability and Growth Pact: Issues and Lessons from Political Economy", International Economics and Economic Policy 2(1), October.

Schuknecht, L., P. Moutot, P. Rother and J. Stark (2011), "The Stability and Growth Pact: Crisis and Reform", Occasional Paper Series no. 129, European Central Bank, September.

Stark, J. (2001), "Genesis of a Pact", in A. Brunila, M. Buti and D. Franco, eds., The Stability and Growth Pact - the Architecture of Fiscal Policy in EMU, Palgrave Publishers, New York.

Trichet, J.-C. (2011), Building Europe, Building Institutions, speech on receiving the 2011 Karlspreis, June.

van Riet, A., ed. (2010), "Euro Area Fiscal Policies and the Crisis", Occasional Paper Series no 109, European Central Bank, April. 